Bijdragen tot de Dierkunde, 58 (1): 105-113 - 1988

\title{
THE GENITAL FIELDS OF CANUELLA PERPLEXA AND C. FURCIGERA (COPEPODA, HARPACTICOIDA) - COMPARATIVE MORPHOLOGY AND FUNCTIONAL ASPECTS
}

\author{
by \\ THOMAS GLATZEL \\ Arbeitsgruppe Zoomorphologie, Fachbereich 7 (Biologie), Universität Oldenburg, \\ Postfach 2503, 2900 Oldenburg, Federal Republic of Germany
}

\begin{abstract}
The harpacticoids Canuella perplexa T. \& A. Scott, 1893 and Canuella furcigera Sars, 1903 differ not only in size and length of the furca, but above all in the structure of the genital fields in both sexes. These differences, which have not been described exactly so far, are demonstrated by SEM micrographs and by drawings. Since there is no adequate terminology for the description of genital fields, terms are introduced in this study. A partly extruded spermatophore in a male specimen of Canuella perplexa is shown by a SEM micrograph. Mating has never been observed in either species; however, from the anatomical structure some conclusions may be drawn on the possible configuration of the genital fields during mating.
\end{abstract}

\section{ZUSAMMENFASSUNG}

Die Harpacticoiden Canuella perplexa T. \& A. Scott, 1893 und Canuella furcigera Sars, 1903 unterscheiden sich nicht nur in der Größe und Länge der Furca, sondern vor allem, was bisher nie eindeutig beschrieben worden ist, im Bau der Genitalfelder beider Geschlechter. Die Unterschiede werden mit rasterelektronenmikroskopischen Aufnahmen und Zeichnungen dokumentiert. Zur Beschreibung gibt es keine adäquate Terminologie. Eine solche wird hier erstmals eingeführt. Am Beispiel des Männchens von Canuella perplexa wird mit einer REM Aufnahme die Offnung der Rima genitalis mit bereits sichtbarer Spermatophore gezeigt. Die Kopula ist bei beiden Arten nie beschrieben worden, doch läßt der Bau Rückschlüsse auf die mögliche Konfiguration der Genitalfelder während der Kopula zu.

\section{INTRODUCTION}

Coexistence of the two closely related species Canuella perplexa and Canuella furcigera in the Wadden Sea raises the question of how confusion is avoided in mate finding. Are there special structures to ensure exact recognition? Sars (1911) and Lang (1948) distinguished both species by means of the length of their furca. Jakubisiak (1938) was not sure at first, whether he had found $C$. perplexa or $C$. furcigera, as his animal resembled $C$. furcigera as to the size of its furca. Having compared the genital fields of both species, however, he decided that he had $C$. perplexa before him without giving definite reasons for his decision.

The descriptions available do not provide a clear idea of the male genital field of $C$. perplexa (see Scott, 1893; Sars, 1911; Klie, 1913; Pesta, 1920, 1926, 1932; Monard, 1928; Dussart, 1967; Damian-Georgescu, 1970; Mielke, 1975). Details have often been drawn, but an exact overall view is still lacking.

\section{MATERIAL AND METHODS}

The canuellids investigated in the present study were caught in the Wadden Sea off the island of Wangerooge (North Sea). Samples were taken along the low water line at low tide and partly from tidal inlets at depths of $3-6 \mathrm{~cm}$ by means of a bottom scraper. Several catches were collected in a container filled with seawater and gently stirred; then the supernatant was filtered through a sieve (mesh $125 \mu \mathrm{m}$ ). For identification of the adults these were fixed in $4 \%$ formalin-seawater, embedded in W15 (Zeiss), dissected and then prepared as permanent mounts in a drop of W15 surrounded by paraffin.

For SEM observation the animals were killed in Ms 222 (ethyl m-amino-benzoate, methanesulfonic acid salt). They stretch passively due to a slackening of the musculature so that the single segments are almost exposed. By means of Ms 222 or in liquid nitrogen the animals may even be fixed in a certain stage. The animals are dehydrated through graded alcohols before being fixed onto SEM slides. 


\section{TERMINOLOGY}

In absence of an adequate terminology the genital fields of Copepoda could as yet not be described in words. Their structure could only be shown in drawings. As a result they still comprise a largely unknown complex of characteristics in spite of its great taxonomic significance (see Heptner, 1968, 1971; Kiefer, 1981). An attempt is made here to introduce a terminology in order to gradually overcome this shortcoming.

The genital field of the male is divided medioventrally by a genital cleft (rima genitalis: $\mathrm{Rmg}$ ). On both sides this cleft is surrounded by a bulge (torus: $\mathrm{Tr}$ ). In the centre of the second abdominal segment there is a tuft (fasciculus: $\mathrm{Fa}$ ) of setae. The cuticule is irregularly covered by chitinous hooklets (chitinous hamuli: $\mathrm{CH}$ ) of different size. This type of cuticular surface is present in both sexes.

The genital field of the female is divided medioventrally by a furrow (sulcus: $\mathrm{Sc}$ ), which is surrounded by a bulge (tumulus: Tu) on both sides. On both sides there is also a skin fold (ruga: $\mathrm{Rg}$ ) leading from the caudal fusion point of the sulcus (Sc) to the paired genital setae and the opening in the area of the genital seta (GS). At these openings (rima genitalis: Rmg) one egg-sac each is produced, supported by two strings (supply tubes?) and the genital seta (GS).

\section{DESCRIPTION OF MALE GENITAL FIELDS}

\section{Canuella perplexa (plate I)}

The genital field (fig. 1) is divided medioventrally by a rima genitalis ( $\mathrm{Rmg})$. This rima is bordered by two tori ( $\mathrm{Tr}$ ) on both sides, caudally tapering off to lanceolate, concave apexes with a tall outer edge. The tori (Tr) and the rima genitalis ( $\mathrm{Rmg}$ ) originate from the centre of the genital segment. The genital field is amply ornamented with areas of small chitinous hamuli $(\mathrm{CH})$. On either side of the base of the rima genitalis (Rmg) a short and behind it - a long seta insert (fig. 2). The latter is stout at its base but is tapering off caudally. The long seta extends to the second half of the second abdominal segment and is provided with small barbules. There is one larger barb on the medial side of the barsal third of the seta. Por (1984) called these setae "petasma". The edges of the rima ( $\mathrm{Rmg})$ are in the proximal half provided with chitinous hamuli $(\mathrm{CH})$ and the distal half ends in a bifurcate seta reaching almost the fasciculus $(\mathrm{Fa})$ on the second abdominal segment. Along the inner side both tori (Tr) are provided with many setae from their middle up to the apex, but the setae do not reach beyond the apex, except for a rather stout one. On both sides of the rima flat, narrow fields of chitinous hamuli $(\mathrm{CH})$ originate basally. These are also ornamented. In the centre of the second abdominal segment there is a drop-shaped fasciculus (Fa) (fig. 3) which is covered by short setae. It is surrounded by thin setulae. One stout seta each, twice as long as the other setae, originates from the centre of the outer sides of the fasciculus $(\mathrm{Fa})$. Ornamentation of the segments extends to the fasciculus $(\mathrm{Fa})$. The genital field from the base of the rima genitalis (Rmg) up to the lanceolate apex of the torus (Tr) has a length of $120 \mu \mathrm{m}$.

\section{Canuella furcigera (plate I)}

The genital field (figs. 5 \& 6) was drawn in detail by Sars (1911). Wilson (1932) described the genital field. Por (1960) and Apostolov (1972) gave further drawings of $C$. furcigera. But none of these drawings show sufficient detail.

Plate I, figs. 1-8: male genital fields.

Figs. 1-4, Canuella perplexa: 1, genital field and second abdominal segment, ventral; 2, frontal part of rima genitalis; 3 , fasciculus; 4 , main characteristics of genital field.

Figs. 5-8, Canuella furcigera: 5, genital field and second abdominal segment, ventral; 6, caudal view of abdomen; 7 , fasciculus; 8 , main characteristics of genital field. 

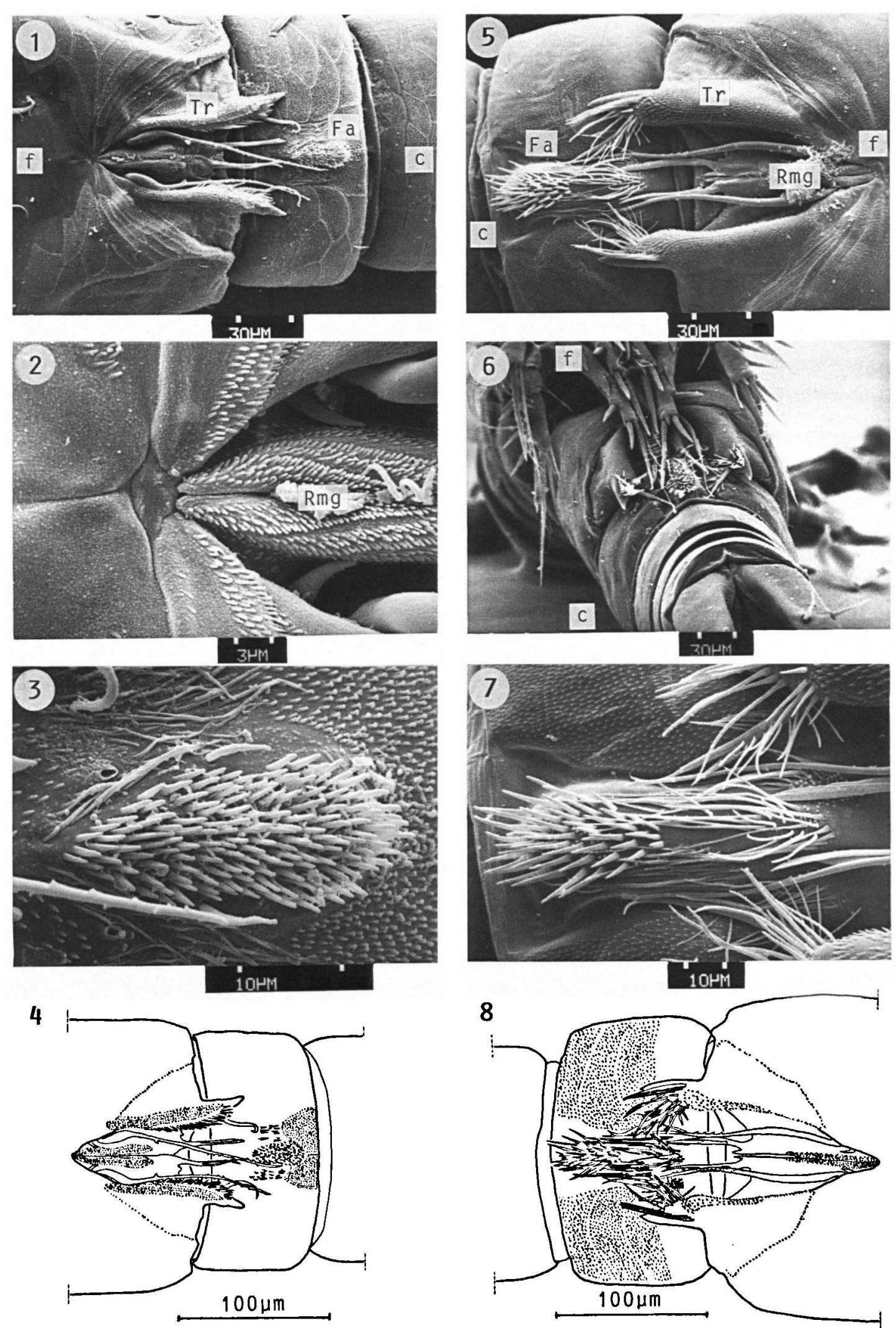
The genital field of $C$. furcigera is - like that of the species described above - medially divided by a rima genitalis ( $\mathrm{Rmg}$ ). The edges of the rima genitalis $(\mathrm{Rmg})$ are slightly vaulted from their base, coarsely ornamented and both end in a short spine on either side, which do not extend beyond the genital field. On the outer side of these spines the edges of the rima genitalis ( $\mathrm{Rmg}$ ) extend into two bifurcate setae reaching the fasciculus $(\mathrm{Fa})$ on the second abdominal segment. Not far from the base of the rima genitalis ( $\mathrm{Rmg}$ ) - to the right and left of the edges of the rima genitalis ( $\mathrm{Rmg}$ ) - a short caudally directed seta originates on either side (see fig. 2). On the same level one long seta each projects on either side, stout at its base but tapering off caudally. This seta extends to the second abdominal segment and is provided with small barbs caudally. The genital field is bordered by two coarsely structured tori (Tr) originating in the centre of the genital field and provided with chitinous hamuli $(\mathrm{CH})$. The tori (Tr) taper caudally into convex apexes, which are densely set with setae along the inner edge and on the ventral surface. A stout, spinulose seta originates on either side from the inner side of the apex of the torus ( $\mathrm{Tr}$ ). There are narrow, ornamented, flat folds laterally on both sides of the base of the rima genitalis (Rmg). The second abdominal segment is roughly structured and extensively ornamented. This ornamentation does not reach the medial fasciculus (Fa) (fig. 7). A funnel-like part of the cuticle in front of and just behind the fasciculus (Fa) remains smooth. The fasciculus $(\mathrm{Fa})$ "divides" the second abdominal segment. It is set with tufts of tiny, thin setae in its frontal area. Then follows a stretch of smooth cuticule. The caudal zone of the fasciculus $(\mathrm{Fa})$ is provided with stout, flat setae, sometimes elongated caudally. The genital field has a length of $162 \mu \mathrm{m}$.

\section{COMPARISON OF MALE GENITAL FIELDS}

Comparison of both male genital fields (figs. 1 $\& 5$, figs. $4 \& 8$ ) and the second abdominal seg- ment reveals distinct differences. The lanceolate apexes of the tori ( $\mathrm{Tr}$ ) point laterally in $C$. perplexa, but medially in $C$. furcigera. The setae of the tori ( $\mathrm{Tr}$ ) are longer, stouter and confined to the apex of the torus ( $\mathrm{Tr}$ ) in $C$. furcigera, whereas they extend medially from the inner side of the tori ( $\mathrm{Tr}$ ) up to their apex in $C$. perplexa. These setae are also significantly smaller. The seta originating from the inner side of the apex of the torus ( $\mathrm{Tr}$ ) is pinnate in $C$. furcigera only. The two long setae inserting near the origin of the rima ( $\mathrm{Rmg}$ ) are provided with one medial spine each in $C$. perplexa. The paired end of the rima ( $\mathrm{Rmg}$ ) is provided with an additional spine in $C$. furcigera. The cuticule of $C$. perplexa is much more delicately and narrowly structured. The second abdominal segment is divided by the fasciculus (Fa), provided with two kinds of setae in $C$. furcigera. Ornamentation reaches up to the caudal zone of the fasciculus (Fa) in $C$. perplexa. Moreover, the tori (Tr) in C. furcigera are about $25 \%$ longer than those in $C$. perplexa.

\section{EXTRUSION OF SPERMATHOPHORE (plate III)}

Fig. 17 shows the genital field of Canuella perplexa with a protruding spermatophore (Sp). The rima genitalis ( $\mathrm{Rmg}$ ) is completely open. Both tori (Tr) and genital setae have been pushed aside. On the outer surface of the tori (Tr) there is a small stretch of very soft cuticle, which forms a fold projecting towards the interior of the rima genitalis $(\mathrm{Rmg})$ while it is open.

\section{DESCRIPTION OF FEMALE GENITAL FIELDS}

Canuella perplexa (plate II)

Examination of the genital field (figs. 9, 10, 11), also described and drawn by T. Scott (1893), Monard (1928), Borutzky (1952) and Por (1960), results in the following details: 
The genital field is richly ornamented by fields of short chitinous hamuli $(\mathrm{CH})$ in its frontal area. Its caudal area has a smooth surface. The genital field is "divided" medioventrally by a sulcus $(\mathrm{Sc})$. There are funnel-shaped tumuli ( $\mathrm{Tu}$ ) pointing frontad on both sides of it. The sulcus (Sc) is completely fused with the genital field frontally, but only in a small area caudally (see fig. 10). The tumuli (Tu) are not fused with the cuticule in their distal area. They are separated from the genital field by a ruga $(\mathrm{Rg})$ externally. This ruga $(\mathrm{Rg})$ originates from the mediocaudal fusion point and ends on both sides at the base of the genital setae (GS), where it is very conspicuous. Underneath the genital seta (GS) is the genital opening (rima genitalis: $\mathrm{Rmg}$ ) with the protruding egg-sac. The genital field has a length of $83 \mu \mathrm{m}$ (measured from the bare apex of the tumuli ( $\mathrm{Tu}$ ) to the beginning of the genital segment).

\section{Canuella furcigera (plate II)}

The genital field (figs. 13, 14, 15) was drawn by Sars (1911). Lang (1948) adopted this drawing. Wilson (1932) gave a more detailed description. Differences between the genital fields in $C$. perplexa and $C$. furcigera were enumerated by Monard (1928). An exact description is given below:

The genital field of $C$. furcigera is "divided" medially by a sulcus $(\mathrm{Sc})$, which is bordered by two somewhat flatter tumuli ( $\mathrm{Tu}$ ) on either side. The caudal area of the sulcus (Sc) is fused with the cuticule at one point only (see fig. 13). Both tumuli ( $\mathrm{Tu}$ ) level out frontally, being completely fused with the cuticule. Ornamentation with chitinous hamuli $(\mathrm{CH})$ is found at the base of the genital setae (GS) only. Position and direction of the ruga $(\mathrm{Rg})$ bordering the genital field are the same as in $C$. perplexa. The rimae genitales (Rmg) on both sides are clearly visible. The apexes of the tumuli (Tu) have a more regular shape than in $C$. perplexa and exceed the fusion line of the two segments forming one genital segment. The overall length from the frontal border of the genital segment to the apexes of the tumuli $(\mathrm{Tu})$ is $133 \mu \mathrm{m}$.

\section{COMPARISON OF FEMALE GENITAL FIELDS}

Comparison of the female genital fields of both species (see figs. 12, 16) clearly reveals a difference in surface structure. Compared with Canuella furcigera, $C$. perplexa has a much richer ornamentation. The genital field in $C$. furcigera is more than $30 \%$ longer, the apexes of its tumuli ( $\mathrm{Tu}$ ) extend to the centre of the genital double-segment. In $C$. perplexa they do not exceed the fusion line. More distinct vaulting of the tumuli ( $\mathrm{Tu}$ ) has often been observed to be followed by formation of new egg-sacs.

\section{DISCUSSION}

There are significant differences between the genital fields of both male and female of the species investigated, a fact unnoticed by Sars (1911). His drawings of genital fields of Canuella furcigera, however, do not belong to this species. As proven in the present study, the genital fields presented by Sars belong to $C$. perplexa instead.

Por (1969, 1984) called the gonopods of the Canuellidae "petasmata". Originally, this term is reserved to the functional unit consisting of parts of the first two pairs of male pleopods in the Malacostraca. In the Canuellidae the appendages of a single segment only contribute to the formation of the copulatory organ. Extending the notion "petasma" to this situation is confusing, since the petasma would thus become a synonym for gonopod in Crustacea.

The function of the striking genital setae in the males could not be observed directly. They are used presumably to recognize the "appropriate" genital field of a female and could also be involved in attaching the spermatophores, as Kiefer (1973) described in the Diaptomidae. When the rima genitalis $(\mathrm{Rmg})$ is completely open (see fig. 17), however, the genital setae are pushed wide apart laterally.

In the Harpacticoida a pre-copulatory phase precedes mating. Female and male form a 

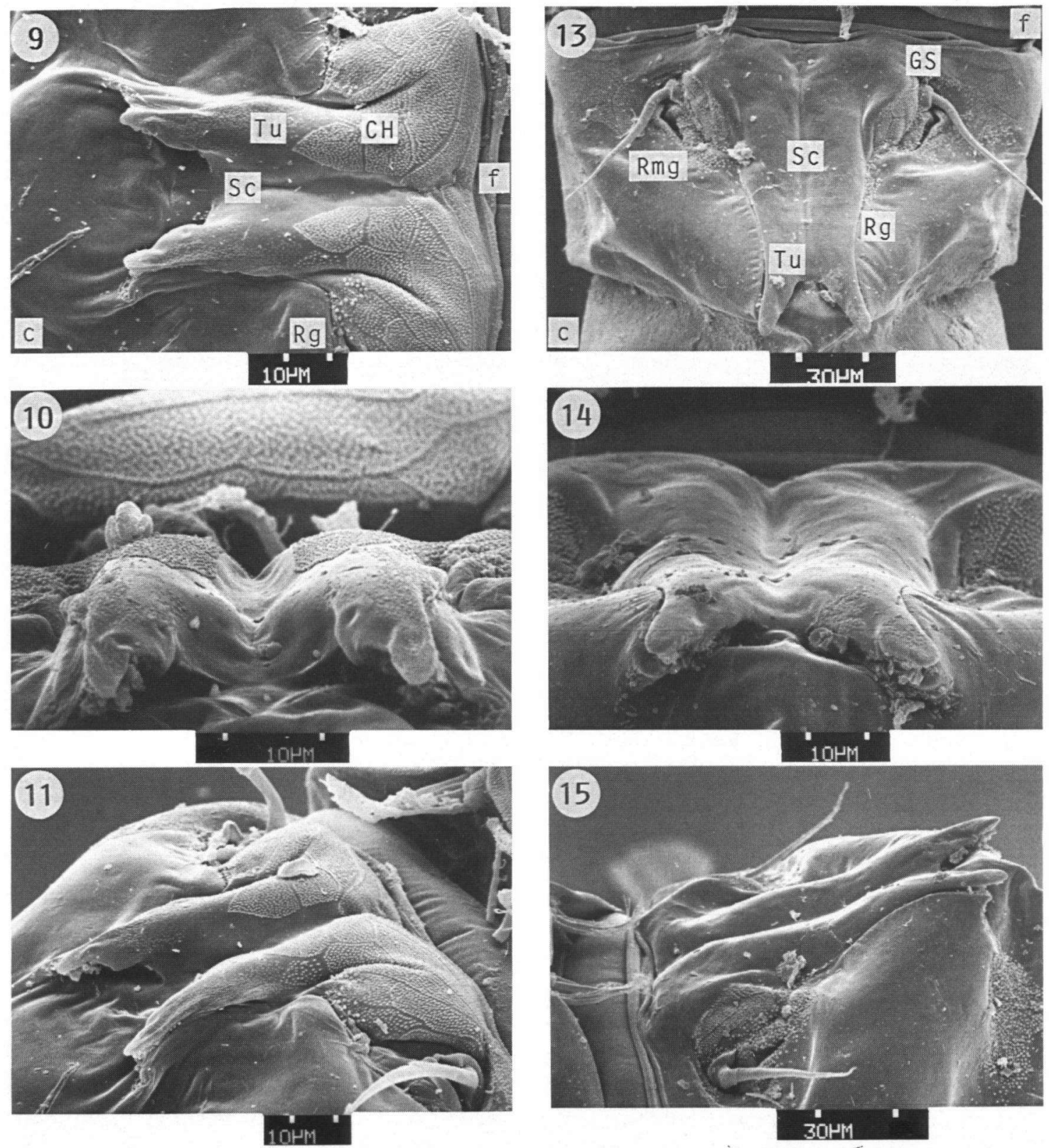

12

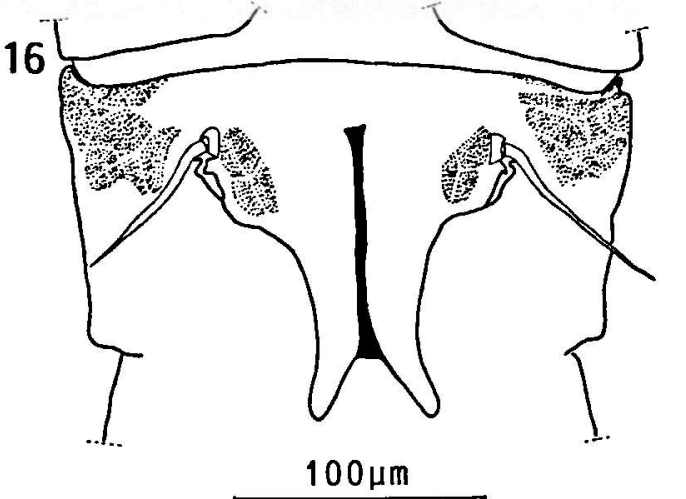


tandem; the male grasps the furca of the female with its first antenna. The pre-copulatory tandem could frequently be observed in $C$. perplexa in the course of the present investigation; however, it seldom looked as Vincx \& Heip (1979) described it. They reported that the male seizes the female's furca swimming with its ventral side pointing downwards, while the female's ventral side is pointing upwards. According to my observations they are much more frequently coupled in equal position, both with their ventral side downwards. The male mostly seizes a furcal ramus of the female with its first left antenna. The first right antenna is only weakly attached, but may also be firmly holding the corresponding furcal ramus. The male releases the female upon intensive lighting. It first releases the right and then the left antenna.

During the pre-copulatory phase the female burrows through the sediment together with the attached male, as Vincx \& Heip (1979) already noticed or it rises to the water surface. Only the female is rowing, sometimes supported by strokes of the male, which even drives the female by pressing its furca.

Mating itself has not yet been observed in Canuella; however, the structure of the genital fields indicates what may happen. It is hardly imaginable that the pre-copulatory phase, as described by Vincx \& Heip (1979), is the starting position for mating. This would require that the male climbs forward on the female's ventral side until their genital fields lie one upon the other. It remains unclear, where the male would find support for its first antenna. Moreover, upon extrusion of one or two spermathophores (fig. 17; see Bacescu et al., 1957; Por, 1960) the overstretched abdomen (see Lang, 1948; Pesta, 1932; Wolf, 1905) would be embarrassing.

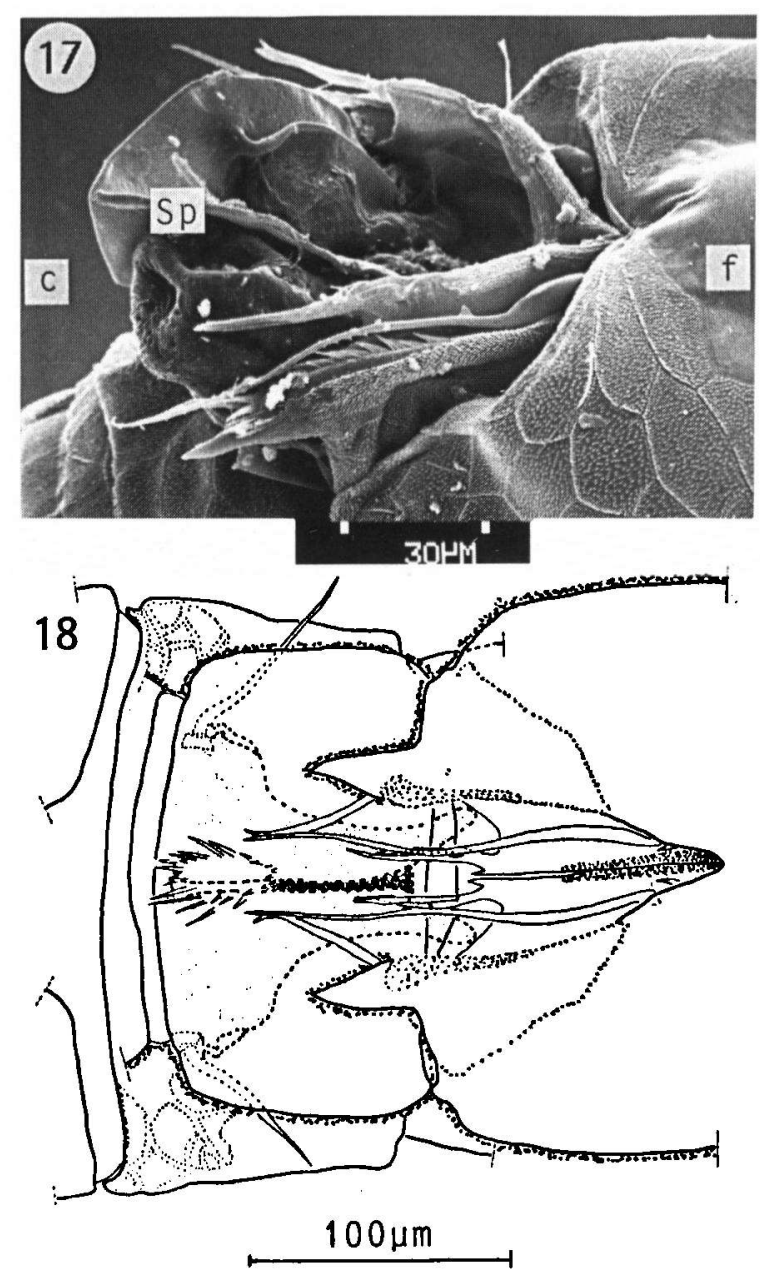

Plate III

Fig. 17, Canuella perplexa, male, extrusion of spermatophore, ventrolateral view.

Fig. 18, Canuella furcigera, genital fields of male and female - probable configuration during mating (figs. $5 * 13$ superimposed, male on top, ventral side down, female below, ventral side up).

The situation becomes quite different, if male and female are in the same position during the pre-copulatory phase. The male could swing to the ventral side of the female and keep clasping

Plate II, figs. 9-16: female genital fields.

Figs. 9-12, Canuella perplexa: 9, partial ventral view of genital field; 10, tumuli, caudal; 11 , total view of genital field; 12, main characteristics of genital field.

Figs. 13-16, Canuella furcigera: 13, genital field, ventral view; 14, tumuli, caudal view; 15 , genital field, lateral view; 16 , main characteristics of genital field. 
its furcal rami. It could examine the female's sulcus (Sc) and genital surface (fig. 18) with its fasciculus $(\mathrm{Fa})$. The configuration of the genital fields may be visualized by copying pictures of the genital fields on transparent foils and putting them one on top of the other accordingly. Palpation with the fasciculus $(\mathrm{Fa})$ could serve as a stimulus for recognizing the right partner and for opening the rima genitalis ( $\mathrm{Rmg}$ ). When the two genital fields lie one upon the other and the abdomen of the male has been folded dorsally (see Lang, 1948: 1512) one spermatophore is attached to the right of the apex of the female's left tumulus (Tu) and a second one to the left of the apex of the right tumulus (Tu) (see Por, 1960).

\section{ABBREVIATIONS USED IN THE FIGURES}

$$
\begin{array}{ll}
\mathrm{c} & =\text { caudal } \\
\mathrm{CH} & =\text { chitinous hamuli } \\
\mathrm{f} & =\text { frontal } \\
\mathrm{Fa} & =\text { fasciculus } \\
\mathrm{GS} & =\text { genital seta } \\
\mathrm{Rg} & =\text { ruga } \\
\mathrm{Rmg} & =\text { rima genitalis } \\
\mathrm{Sc} & =\text { sulcus } \\
\mathrm{Sp} & =\text { spermatophore } \\
\mathrm{Tr} & =\text { torus } \\
\mathrm{Tu} & =\text { tumulus }
\end{array}
$$

\section{ACKNOWLEDGEMENTS}

I am very much obliged to Prof. Dr. H. K. Schminke (Oldenburg) and Dr. J. W. Wägele (Oldenburg) for their support during this study and I am grateful to Mrs. S. Seufer for her technical assistance in the production of the SEM micrographs. Mrs. A. Sievers kindly helped with the English text. Thanks are also due to my parents who financially supported my studies.

\section{REFERENCES}

Apostolov, A., 1972. Catalogue des Copépodes Harpacticoïdes marins de la Mer Noire. Zool. Anz., 188 (3/4): 202-254.

Bacescu, M., H. Dumitrescu, V. Manea, F. Pór \& R. MAYer, 1957. Les sables à Corbulomya (Aloidis) maeotica Mill. - Base trophique de premier ordre pour les poissons de la Mer Noire. Trav. Mus. Hist. nat. "Gr. Antipa", 1: 305-374.
BoRUtzky, E. V., 1952. Freshwater Harpacticoida. Fauna U.S.S.R., 3 (4): 1-389 (Israel Program for Scientific Translations, Jerusalem, 1964).

Damian-Georgescu, A., 1970. Copepoda, Harpacticoida. Fauna Republicii Socialiste România, 4 (11): 1-252 (Academia Republicii Socialiste România, Bucarest).

Dussart, B., 1967. Calanoïdes et Harpacticoïdes. Les Copépodes des eaux continentales, 1: 1-500 (Boubée \& Cie, Paris).

Heptner, M. V., 1968. Structure and taxonomic significance of the genital complex of copepods of the family Euchaetidae (Calanoida). Okeanologija, 8 (4): 680-692 [In Russian with English summary].

- - 1971. To the copepod fauna of the KurkileKamchatka trench. The families Euchaetidae, Lucicutiidae, Heterorhabdidae. Trudy Inst. Okeanol., 92: 73-161 [In Russian with English summary].

Jakubisiak, St., 1938. Les Harpacticoïdes de la Mer Noire. Annls. scient. Univ. Jassy, 24: 387-402.

Kiefer, F., 1973. Ruderfußkrebse (Copepoden): 1-97 (Frankh'sche Verlagshandlung, W. Keller \& Co., Stuttgart).

- - 1981. Beitrag zur Kenntnis der Morphologie, Taxonomie und geographischen Verbreitung von Mesocyclops leuckarti auctorum. Arch. Hydrobiol. (Suppl.), 62: 148-190.

Klie, W., 1913. Die Copepoda Harpacticoida des Gebietes der Unter- und Außenweser und der Jade. Schr. Ver. Naturk. Unterweser, 3: 1-49.

LANG, K., 1948. Monographie der Harpacticiden, 1 \& 2: 1-1682 (Reprint 1975, Otto Koeltz Sci. Publ., Koenigstein).

Mielke, W., 1975. Systematik der Copepoda eines Sandstrandes der Nordseeinsel Sylt. Mikrofauna Meeresbodens, 52: 1-134.

Monard, A., 1928. Les Harpacticoïdes marins de Banyuls. Archs. Zool. exp. gén., 67: 259-443.

Pesta, O., 1920. Die Planktoncopepoden der Adria. Zool. Jb. (Syst.), 43: 471-660, pl. 8.

-, 1926. Crustacea, Copepoda und Cladocera aus dem Litoral des Schwarzen Meeres. Archs. Hydrobiol., 16: 606-608.

- 1932 . Ruderfüßer oder Copepoda. In: F. DAHL ed., Tierwelt Deutschl., 24: 1-164 (Gustav Fischer, Jena).

Por, F. D., 1960. Litorale Harpacticoiden der NordwestKüsten des Schwarzen Meeres. Trav. Mus. Hist. nat. "Gr. Antipa", 2: 97-143.

- - 1969. The Canuellidae (Copepoda, Harpacticoida) in the waters around the Sinai peninsula and the problem of "Lessepsian" migration of this family. Israel J. Zool., 18: 169-178.

- - 1984. Canuellidae Lang (Harpacticoida, Polyarthra) and the ancestry of the Copepoda. Crustaceana, Suppl. 7: 1-24. 
Sars, G. O., 1911. Copepoda, Harpacticoida. In: An account of the Crustacea of Norway, 5: 1-449 (Bergen Museum, Bergen).

ScotT, T., 1893. Addition to the fauna of the Firth of Forth. Annual Rep. Fishery Board Scotland, 11 (3): 200-202, pl. II.

Scotr, T. \& A. Scotr, 1893. Notes on Copepoda from the Firth of Forth. Ann. Scot. nat. Hist., 2: 89-94, pl. II (issued in the July number, 1893).
Vincx, M. \& C. Heip, 1979. Larval development and biology of Canuella perplexa T. \& A. Scott, 1893 (Copepoda, Harpacticoida). Cah. Biol. mar., 20: 281-299.

Wilson, C. B., 1932. The copepods of the Woods Hole region Massachusetts. Bull. U.S. natn. Mus., 158: 1-623.

Wolf, E., 1905. Die Fortpflanzungsverhältnisse unserer einheimischen Copepoden. Zool. Jb. (Syst.), 22: 101-280, pls. 7-8.

Received: 14 October 1987

Revised: 10 January 1988 